\title{
QUALIDADE DA ÁGUA NAS ÁREAS ATERRADAS COM ENTULHO EM UBERLÂNDIA, MINAS GERAIS, BRASIL.
}

\section{WATER QUALITY IN THE AREAS COVERED BY WASTE MATERIAL AT UBERLÂNDIA, MINAS GERAIS, BRAZIL.}

\section{Rocha, A. L.1, Nishiyama, L.²; Bellingieri, P. H. ${ }^{3}$}

${ }^{1}$ Bióloga e Mestre em Geografia, pela Universidade Federal de Uberlândia.

${ }^{2}$ Geólogo e Prof. Dr. do Instituto de Geografia, da Universidade Federal de Uberlândia.

${ }^{3}$ Engenheiro Civil e Mestrando em Engenharia, pela UNICAMP.

\section{RESUMO}

Nos dias atuais o reaparecimento de várias doenças nas áreas urbanas evidencia a pouca atenção dispensada ao saneamento básico e ao manejo correto e eficiente dos resíduos sólidos, incluindo-se o entulho. Dessa forma, foram coletadas amostras de água em três pontos diferentes da cidade de Uberlândia-MG, aterrados com entulho e outros resíduos sólidos associados. Este estudo demonstrou através da análise química, que há realmente sinais de contaminação das águas subterrâneas e o monitoramento precisa ser ampliado, tanto em relação aos parâmetros analisados quanto ao número de pontos de amostragem. Também, deve-se destacar que os níveis de contaminação detectados confrontam às leis ambientais brasileiras e alertam que o aterro não é o melhor destino para este dejeto.

Palavras-chave: qualidade da água, entulho, impacto ambiental, manejo de resíduos.

\begin{abstract}
Nowadays the reappearing of several diseases at urban areas gives evidence of a negligence for the basic sanitation and the correct (efficient) waste management, including the waste material. In such case, it was collected water samples at three different places at Uberlândia-MG, (Brazil), from areas covered by debris, waste material and other solid residues landfill. So, this study has shown by the chemical analysis that there are signs of subterranean water contamination and it is necessary
\end{abstract}


to extend the research with more parameters to be analyzed and, also to increase the number of samples. Thus, the contamination signs are not following the Brazilian environmental regulations and the landfill at Uberlândia is not best place for the debris.

Key words: water quality, waste material, environmental impact, waste management.

\section{INTRODUÇÃO}

A preocupação em preservar a saúde já aparece na sociedade humana, desde os períodos mais remotos. Na Idade Antiga, a relação das pessoas com o ambiente pode ser notada pela escolha dos locais para a construção das vilas e cidades. Elas eram sempre instaladas nos lugares considerados mais seguros e saudáveis, bem arejados e iluminados. Roma, capital do Império Romano, e Atenas, principal cidade grega, foram edificadas em locais onde o clima era agradável e os mananciais hídricos abundantes. Partindo-se dos primeiros estudos do sanitarismo, realizados por Hipócrates (Pai da Medicina), essas idéias ficam evidenciadas na demonstração de uma correlação direta entre a higienização do corpo individual e do ambiente físico e social (SILVA et al., 1997). Com o desenvolvimento das ciências relacionadas à saúde, esses conceitos, defendidos na Idade Antiga, resgatam seu "status" no pensamento dos séculos XVIII e XIX; as pessoas passaram a dispor de mais informações sobre o que é bom e o que é nocivo a sua saúde. Um resultado da transformação sócio-econômica gerada, especialmente, pela Revolução Industrial (COSTA, 1987; SILVA et al., 1997).

Movidos pelas mudanças sociais, políticas e econômicas, além das grandes epidemias (por elas impulsionadas); sanitaristas, políticos e filósofos, tais como Engels, Chadwick, Snow, Hobsbawn, debateram sobre essas idéias, a fim de se estabelecer normas e padrões de conduta, inclusive sanitária. E a teoria miasmática do século XIX - "as febres epidêmicas tinham origem na matéria animal e vegetal em putrefação, nas águas estagnadas e na má circulação de ar" - sendo difundida na aplicação dos programas de prevenção e reestruturação do ambiente urbano (COSTA, 1987; SILVA et al., 1997).

Segundo Costa (1987), todos esses esforços, na verdade, não tiveram cunho estritamente social; as leis sanitárias objetivaram extinguir as epidemias que ameaçavam o progresso e os interesses da sociedade burguesa e legitimar a expulsão das populações pobres para os entornos urbanos e/ou cortiços.

De acordo com a Fundação Nacional de Saúde (FUNASA, 2001), a intensa urbanização e industrialização, com suas repercussões nas condições de vida e trabalho das pessoas, acompanhadas das ações de controle das doenças infectocontagiosas e do aumento da expectativa de vida, fizeram com que o quadro de morbi-mortalidade passasse por mudanças significativas ao longo do último século, 
embora de forma mais tardia e complexa nos países de industrialização recente e economia periférica.

Minc (1997) definiu a situação das grandes cidades da seguinte maneira: “A grande cidade agoniza: asfixiada por monóxido de carbono, cercada de lixo químico, sitiada pelos guetos que a desigualdade criou, vitimada pela leptospirose de ratos e picada pelos mosquitos da Dengue".

Assim, a poluição afeta a todos, ricos e pobres, mas em especial aqueles expostos ao contato direto com o agente poluidor.

Nos dias atuais, o reaparecimento de várias doenças nas áreas urbanas evidência a pouca atenção dispensada ao saneamento básico e ao manejo correto e eficiente do lixo, incluindo-se o entulho. Há muito o Brasil é exemplo desse problema, pois, segundo o último levantamento realizado pela Associação Brasileira de Engenharia Sanitária e Ambiental (ABES), em 1993, 80\% das consultas e 65\% das internações realizadas no país, no ano de 1992, tiveram como causas principais à falta de água potável e de saneamento básico. Mais alarmante ainda, os dados mostraram que, 925 dos municípios brasileiros não possuíam tratamento de esgotos, 59\% não possuíam destinação final para o lixo e em $58 \%$ não havia água tratada segundo Conselho Regional de Engenharia, Arquitetura e Agronomia de Minas Gerais, (CREA-MG, 1998).

Em "tempos de Dengue", deve-se ressaltar que a proliferação de seu vetor Aedes aegypti - está mais diretamente relacionada com o acúmulo de lixo e a limpeza urbana. Em lotes vagos, ferros-velhos e borracharias, o mosquito encontra ambiente propício, já que eles servem como reservatórios de água parada. Isto é mais bem exemplificado pela descoberta do Aedes albopictus, um vetor menos exigente que o Aedes aegypti, capaz de se reproduzir em água suja e poluída (CREA-MG, 1998).

Assim, o objetivo desta pesquisa foi avaliar quimicamente (qualitativa e quantitativamente) o grau de contaminação, ocorrido na cidade de Uberlândia, Minas Gerais (Brasil), em áreas aterradas com entulho e outros resíduos sólidos: pois, o entulho da construção civil, misturado a outros tipos de resíduos sólidos, é passível de contaminar o solo e as águas superficiais e subterrâneas, se utilizado para fins de aterramento em áreas de erosão (voçorocas) (ROCHA, 2000).

\section{MATERIAIS E MÉTODOS}

O conhecimento prévio advindo do estudo desenvolvido entre 1999 e 2000 (ROCHA, 2000), das áreas do município de Uberlândia em seu perímetro urbano aterradas com entulho, resultou na escolha de três locais para avaliação da qualidade da água:

Aterro do bairro Aclimação (ponto 01) - Originalmente era uma grande erosão, desenvolvida há cerca de 40 anos, junto à nascente do Córrego Perpétua, provavelmente em decorrência da ação antrópica (exploração de 


\begin{tabular}{|l|r|}
\hline Recebido em: $18 / 05 / 2005$ & HOLOS Environment, v.5 n.1, 2005 - P. 84 \\
\hline Liberado para Publicação em: $14 / 10 / 2005$ & ISSN: $1519-8634$ \\
\hline
\end{tabular}

saibro). A partir de 1.999 esta área foi aterrada pela Prefeitura Municipal de Uberlândia com resíduos da construção civil associados a outros tipos de resíduos sólidos, aos quais se incluem resíduos domiciliares e comerciais (ROCHA, 2000). A água da nascente existente no interior da erosão foi drenada à jusante do aterro. Dessa forma, a coleta de amostras de água foi realizada na saída do dreno.

- Aterro do bairro Santa Rosa (Ponto 02) - A grande erosão desenvolvida em decorrência da ação antrópica foi, a partir de 1996, aterrada com entulho da construção civil e outros tipos de resíduos sólidos. Em procedimento semelhante ao aterro do bairro Aclimação, o curso d'água existente no interior da erosão foi drenado e canalizado para a porção jusante do aterro. A coleta da água foi realizada na saída do dreno.

* Aterro do bairro Morumbi (ponto 03) - Em 2.001 foram dispostos e aterrados resíduos de construção civil e outros tipos de resíduos sólidos em cavas existentes às margens da BR365. Em razão do não exposição da água subterrânea fez-se necessária à perfuração de um poço até o nível do lençol freático para coleta e monitoramento. A perfuração do poço foi realizada sob orientação do Prof. Dr. Luiz Nishiyama (UFU) e do Eng. Civil Franklin Moreira (Secretaria Municipal de Obras), por seu profundo conhecimento da área em questão, utilizando-se um trado manual até a profundidade de 10 metros, cerca de 2 metros abaixo do limite entre a zona insaturada e saturada (superfície piezométrica) do solo.

O poço foi, então, revestido internamente por um tubo de PVC de $75 \mathrm{~mm}$ de diâmetro perfurado ao longo de sua extensão para permitir a entrada da água e revestida com manta geotextil (Bidim), para impedir a entrada de materiais finos do solo carreados pela água para o interior do poço. Cerca de $1 \mathrm{~m}$ do tubo de PVC ficou acima do solo e foi fechado com uma tampa confeccionada com o mesmo material.

Definiu-se também um ponto de referência para as análises físico-químicas. Considerou-se, como critério para a escolha deste ponto, um local relativamente próximo (dentro do mesmo bairro) e isento de influência dos resíduos dispostos. $\mathrm{O}$ local escolhido foi um poço domiciliar, tipo cisterna, localizado à montante do aterro, à Rua Antônio Francisco Rosa n ${ }^{\circ} 65$.

As coletas foram feitas de acordo com a sazonalidade climática da região, caracterizada por duas estações bem definidas: uma estação chuvosa que corresponde aos meses de outubro a março e, a outra, seca que compreende o período que se estende de abril a setembro. A adoção deste critério para as amostragens deve-se a sazonalidade climática que, por sua vez, influencia na maior ou menor quantidade de água percolada através da superfície do aterro e, conseqüentemente, a quantidade e o transporte de contaminantes.

As amostras referentes ao período de seca foram coletadas no dia 26 de setembro de 2002, portanto, no auge da seca, no período da manhã, com temperatura 
ambiente em torno de $20^{\circ} \mathrm{C}$ e, a quantidade de água amostrada para cada ponto foi em média, 1,5 L. Nos pontos 01 (aterro do bairro Aclimação), 02 (aterro do bairro Santa Rosa) as amostragens foram realizadas em locais de surgência. $\mathrm{O}$ recipiente coletor foi apoiado pela base e submerso até uma profundidade de $20 \mathrm{~cm}$ da superfície, de modo que, a boca do recipiente ficasse voltada contra o da corrente. Em seguida, com o auxílio de um funil, o conteúdo foi transferido a um recipiente de vidro de coloração âmbar, previamente etiquetado com as seguintes informações Companhia Tecnologia e Saneamento Ambiental de São Paulo (CETESB, 1974):

- Nome do coletor;

口 N. ${ }^{\circ}$ do ponto de coleta;

- Data;

- Horário;

- Temperatura da água;

- Temperatura ambiente; e,

- Quantidade de água coletada.

Também, no dia 26/09/02, no ponto 03 (aterro do bairro Morumbi) a coleta foi realizada, no poço de monitoramento, utilizando um recipiente coletor construído com um tubo de PVC de uma polegada e munido de um retentor de água na extremidade inferior, com capacidade de $100 \mathrm{ml}$ e preso na outra extremidade a um cordão de comprimento suficiente para atingir o NA $(9 \mathrm{~m})$. Durante a amostragem procurou-se descer o coletor através do poço sem tocar nas suas laterais e submergir completamente na água, contudo sem tocar no fundo para não colocar em suspensão os materiais finos (argila) ali depositados. Uma vez cheio, ele era recolhido à superfície onde imediatamente se procedia à medição da temperatura e, em seguida, $\mathrm{o}$ seu conteúdo era cuidadosamente repassado a um recipiente de coleta, previamente etiquetado, como descrito acima. Este procedimento de coleta de água foi repetido 10 vezes para se obter o volume de 1 litro.

As coletas no período chuvoso aconteceram em 2 etapas:

I. No dia 29 de novembro de 2002, no ponto 02 ; já que, nos outros locais o atraso das chuvas interferiu radicalmente no volume de água para coleta; e,

II. No dia 10 de janeiro de 2003, nos pontos 01 e 03 . Entretanto, o ponto 03 teve toda a sua faixa institucional de $30 \mathrm{~m}$, onde estava localizado o poço de monitoramento, aterrada com entulho e outros tipos de resíduos sólidos pelo município. Assim, a coleta foi impossibilitada.

Quanto aos pontos 01 e 02 , os procedimentos aconteceram no período da tarde; em razão de chuvas intensas que aconteceram no período da manhã. A temperatura ambiente estava em torno de $31^{\circ} \mathrm{C}$ e, a quantidade média amostrada para cada ponto foi de $1,5 \mathrm{~L}$.

Todas as amostras tão logo coletadas foram encaminhadas ao Instituto de Química/Diretoria de Assessoramento Técnico e Análise Química (DIAAQ)/Universidade Federal de Uberlândia. 
O material foi analisado de acordo com as exigências previstas nas Normas Brasileiras (NBRs) e da Legislação Ambiental Brasileira para os Recursos Hídricos Resolução no 20 , de 18 de junho de 1986, do CONAMA.

O quadro 01, a seguir, apresenta os aspectos metodológicos empregados pelo referido laboratório para esta etapa do estudo.

QUADRO 01 - Aspectos metodológicos empregados para análise das amostras de água, pela DIAAQ/IQ/UFU.

\begin{tabular}{|c|c|c|c|c|}
\hline PARÂMETROS & NBR & APARELHAGEM & MARCA & $\begin{array}{c}\text { OBJETIVO DA } \\
\text { ANÁLISE }\end{array}$ \\
\hline $\mathrm{pH}$ & 9251 & phmetro & Digimed & $\begin{array}{l}\text { Determinação do pH em } \\
\text { amostras de corpos d'água } \\
\text { em geral, águas de } \\
\text { abastecimento, águas } \\
\text { salinas, residuárias, } \\
\text { domésticas e industriais. }\end{array}$ \\
\hline TEMPERATURA & - & $\begin{array}{l}\text { Termômetro (de } 10^{\circ} \mathrm{C} \text { a } 50^{\circ} \\
\text { C) }\end{array}$ & & - \\
\hline $\mathrm{DBO}$ & 12614 & Digestor para $\mathrm{DBO}$ & Tecnal & $\begin{array}{l}\text { Determinação da demanda } \\
\text { bioquímica de oxigênio } \\
\text { (DBO) em amostras de } \\
\text { coleções líquidas em geral, } \\
\text { efluentes domésticos e } \\
\text { industriais, lodos e água do } \\
\text { mar. }\end{array}$ \\
\hline $\mathrm{DQO}^{1}$ & 10357 & Digestor para DQO & Marconi & $\begin{array}{l}\text { Determinação da demanda } \\
\text { química de oxigênio (DQO) } \\
\text { em águas superficiais e } \\
\text { residuárias. }\end{array}$ \\
\hline DUREZA $^{2}$ TOTAL & 5760 & $\begin{array}{l}\text { Aparelhagem convencional de } \\
\text { química analítica }\end{array}$ & - & $\begin{array}{l}\text { Determinação de cálcio em } \\
\text { águas naturais, tratadas e de } \\
\text { caldeiras, empregando-se o } \\
\text { sal dissódico de ácido } \\
\text { etileno diamino tetracético } \\
\text { (EDTA). }\end{array}$ \\
\hline DUREZA DE CÁLCIO & 5760 & $\begin{array}{l}\text { Aparelhagem convencional de } \\
\text { química analítica }\end{array}$ & & $\begin{array}{l}\text { Determinação de cálcio em } \\
\text { águas naturais, tratadas e de } \\
\text { caldeiras, empregando-se o } \\
\text { sal dissódico de ácido } \\
\text { etileno diamino tetracético } \\
\text { (EDTA). }\end{array}$ \\
\hline ALUMÍNIO & 15814 & $\begin{array}{l}\text { Espectrofotômetro de absorção } \\
\text { atômica }\end{array}$ & CG.AA.905 & $\begin{array}{l}\text { Determinação de alumínio } \\
\text { em águas minerais e de } \\
\text { mesa, por espectrofotometria } \\
\text { de absorção atômica. }\end{array}$ \\
\hline CÁDMIO & $\begin{array}{c}11014 \\
\mathrm{MB}-3156\end{array}$ & $\begin{array}{l}\text { Espectrofotômetro de absorção } \\
\text { atômica }\end{array}$ & CG.AA.905 & $\begin{array}{l}\text { Determinação de cádmio em } \\
\text { águas minerais e de mesa, } \\
\text { por espectrofotometria de } \\
\text { absorção atômica. }\end{array}$ \\
\hline CHUMBO & $\begin{array}{c}11016 \\
\mathrm{MB}-3157\end{array}$ & $\begin{array}{l}\text { Espectrofotômetro de absorção } \\
\text { atômica }\end{array}$ & CG.AA.905 & $\begin{array}{l}\text { Determinação de chumbo } \\
\text { em águas minerais e de } \\
\text { mesa, por espectrofotometria } \\
\text { de absorção atômica. }\end{array}$ \\
\hline
\end{tabular}

FONTE: DIAAQ/IQ/UFU, 2003.

\footnotetext{
${ }^{1}$ DQO (DEMANDA QUÍMICA DE OXIGÊNIO). Trata-se da medida da quantidade de agente oxidante químico energético necessário para oxidar a matéria orgânica de uma amostra, expressa em unidades equivalentes à mg de $\mathrm{O}_{2}$ por litro. Segundo a NBR 10357, um valor aceitável seria em torno de160 $\mathrm{mg} \mathrm{O}_{2}$ / L; ou seja, uma média entre os três métodos possíveis de análise (Refluxo Aberto, Refluxo Fechado Titulométrico e Refluxo Fechado Colorimétrico) (CETESB, 1974).

${ }^{2}$ Dureza da água. Quase toda ela provém do cálcio e do magnésio, que contribuem para a incrustação que se produz quando a água passa por mudanças de temperatura e de pressão. A dureza total pode ser dividida em duas partes: a dureza de carbonato - é a da porção do cálcio e do magnésio suscetível de se combinar com o bicarbonato e a pequena quantidade de carbonato presente -; e, a dureza de não carbonato - que é a diferença entre a dureza total e a dureza de carbonato. É causada pelo cálcio e magnésio que se combinam com íons sulfato, cloreto e nitratos presentes. Uma dureza de 50 a $150 \mathrm{ppm}$ não é objetável para a maioria dos usos da água. Acima de $150 \mathrm{ppm}$ ela é decididamente perceptível (CETESB, 1974).
} 


\section{RESULTADOS E DISCUSSÃO}

Para uma melhor compreensão dos resultados, é preciso conhecer os princípios normativos que regem o assunto.

A qualidade de uma determinada água está relacionada à sua função de uso e da ocupação do solo na bacia hidrográfica. Desse modo a Resolução n. ${ }^{\circ}$ 20/86 do CONAMA diz respeito á corpos d'água superficiais e os classifica em 8 classes diferentes:

- CLASSES I, II, III, IV - ÁGUAS DOCES = Águas com salinidade igual ou inferior a $0,50 \%$;

- CLASSES V e VI - ÁGUAS SALOBRAS = Águas com salinidade igual ou inferior a $0,50 \%$ e $30 \%$; $e$,

- CLASSES VII e VIII - ÁGUAS SALINAS = Águas com salinidade igual ou superior a $30 \%$.

Entretanto, no caso de um estudo como este em que houve amostra coletada num poço de monitoramento, se faz uma comparação de valores a partir desta Resolução, observando-se que as águas analisadas poderiam ser enquadradas na Classe III com base nos parâmetros analisados; desde que se considerassem outros parâmetros como o oxigênio dissolvido (OD), coliformes totais e fecais etc.

Vale ressaltar, que os parâmetros acima descritos não contemplam a todos aqueles analisados pelo DIAAQ para este estudo. Por essa razão, foi necessária uma consulta à literatura científica especializada para esclarecer os limites aceitos, quanto a DQO e a Dureza da água (CETESB, 1974).

Mediante tais informações, é possível realizar a análise dos resultados (TABELAS 01 e 02).

TABELA 01 - Resultados da análise das amostras coletadas no período seco (Setembro/2002).

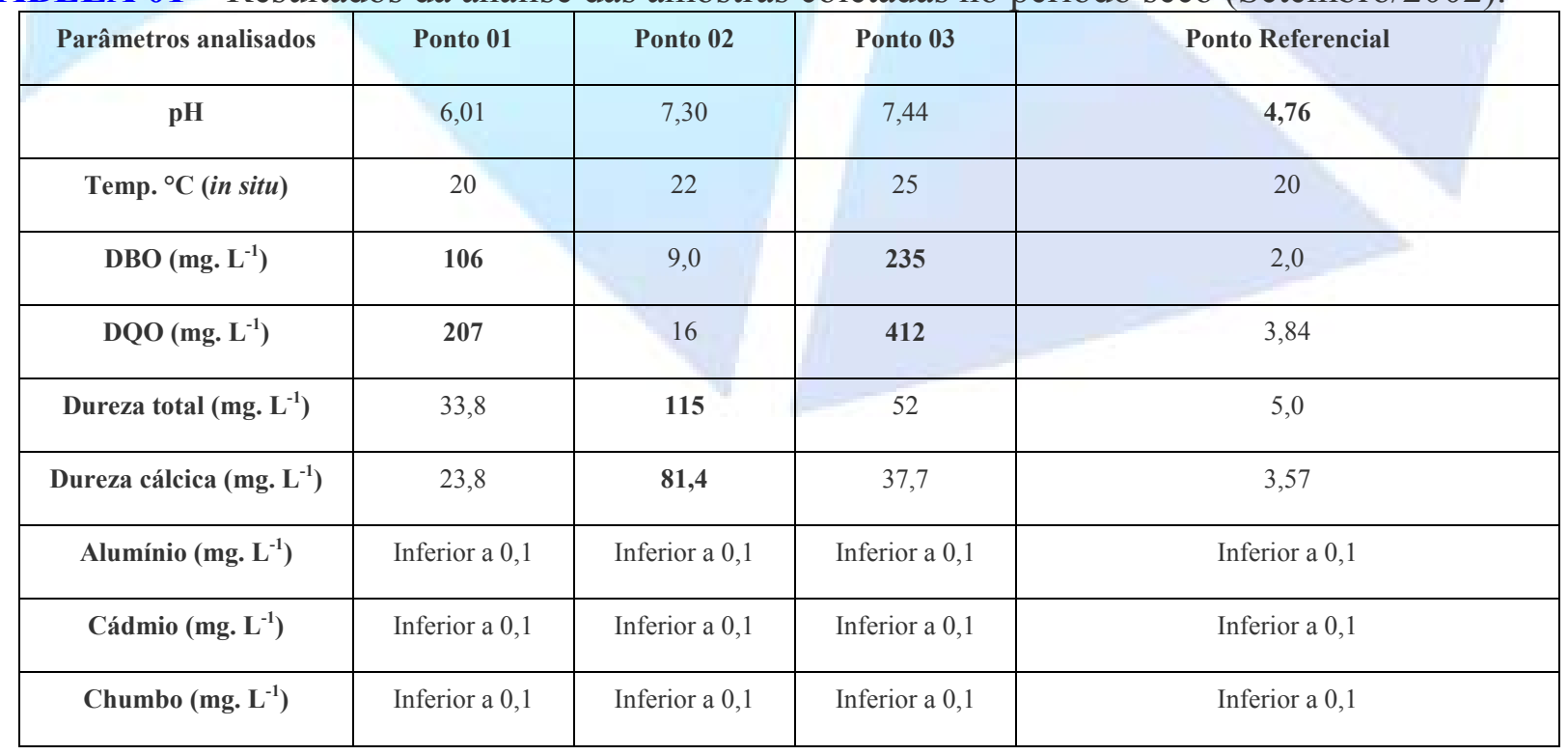

Fonte: DIAAQ/IQ/UFU, 2002. 
TABELA 02 - Resultados da análise das amostras coletadas no período chuvoso (Novembro/2002 - ponto 02, Janeiro/2003 - ponto 01).

\begin{tabular}{|c|c|c|c|c|}
\hline Parâmetros analisados & Ponto 01 & Ponto 02 & Ponto 03 & Ponto Referencial \\
\hline pH & 6,76 & 7,02 & Sem dados & 4,76 \\
\hline Temp. ${ }^{\circ} \mathrm{C}$ (in situ) & 28 & 25 & Sem dados & 20 \\
\hline DBO (mg. $\left.\mathbf{L}^{-1}\right)$ & 237 & 6,0 & Sem dados & 2,0 \\
\hline DQO (mg. L $\left.{ }^{-1}\right)$ & 440 & 11,0 & Sem dados & 3,84 \\
\hline Dureza total $\left(\mathrm{mg} . \mathrm{L}^{-1}\right)$ & 126 & 208,5 & Sem dados & 5,0 \\
\hline Dureza cálcica (mg. L $\left.{ }^{-1}\right)$ & 93 & 145,0 & Sem dados & 3,57 \\
\hline Alumínio (mg. L $\left.{ }^{-1}\right)$ & Inferior a 0,1 & 0,5 & Sem dados & Inferior a 0,1 \\
\hline Cádmio (mg. $\left.\mathrm{L}^{-1}\right)$ & Inferior a 0,1 & Inferior a 0,1 & Sem dados & Inferior a 0,1 \\
\hline Chumbo (mg. $\left.\mathbf{L}^{-1}\right)$ & Inferior a 0,1 & Inferior a 0,1 & Sem dados & Inferior a 0,1 \\
\hline
\end{tabular}

Fonte: DIAAQ/IQ/UFU, 2002 e 2003.

Com relação ao potencial hidrogeniônico $(\mathrm{pH})$, observou-se que os valores estão dentro dos padrões do CONAMA - 6,0 a 9,0 -, tanto no período seco (Ponto 01 - 6,01; Ponto $02-7,30$; Ponto 03 - 7,44) quanto no chuvoso (Ponto $01-6,76$; Ponto 02 - 7,02; Ponto 03 - sem dados). Este parâmetro está relacionado com a capacidade de corrosão e incrustação de sistemas. A concentração relativa de íons hidrogênio na água indica se essa atua como um ácido fraco ou como uma solução alcalina. Assim, quando a quantidade de hidrogênio é excessiva em relação aos outros íons, resulta uma reação ácida e, águas com esse comportamento tendem a atacar os metais. A escala de $\mathrm{pH}$ é expressa da seguinte forma: um $\mathrm{pH}$ igual a 7,0 indica uma solução neutra, menor do que 7,0 uma condição ácida e maior do que 7,0 uma solução alcalina (CETESB, 1974). A única exceção foi o Ponto Referencial, cujo valor de pH encontrado foi 4,76. Embora seja considerada uma água ácida, a acidez mineral aquela proveniente de uma fonte estranha, que não simplesmente do gás carbônico (BRANCO, 1972) - só se verifica com pH inferior a 4,5 (CETESB, 1974).

Quanto a DBO e a DQO, antes de qualquer comentário dos resultados, é preciso relembrar a dinâmica do oxigênio para a sobrevivência dos organismos vivos. $\mathrm{O}$ oxigênio necessário à vida é encontrado em estado gasoso na atmosfera, onde sua proporção é de $21 \%$ aproximadamente. A água livre de poluição e em contato com o ar atmosférico é capaz de dissolver o oxigênio até uma certa quantidade máxima, definida pelo ponto de saturação que depende da pressão e da temperatura. Por exemplo, ao nível do mar (1 atm ou $760 \mathrm{~mm} \mathrm{Hg}$ de pressão), o ponto de saturação do oxigênio na água é de $14,6 \mathrm{mg} . \mathrm{L}^{-1}$ a $0^{\circ} \mathrm{C}$ e de $10,2 \mathrm{mg} . \mathrm{L}^{-1}$ a $15^{\circ} \mathrm{C}$. Disposta no terreno uma massa de matéria orgânica sofrerá decomposição na presença de oxigênio (aeróbia) apenas na superfície exposta. Em seu interior, onde o oxigênio do ar não 
tem acesso, ocorrerá à decomposição anaeróbia. Entretanto, se a mesma for diluída em grande volume de água contendo oxigênio dissolvido, o processo pode ser totalmente aeróbio, já que essas condições propiciam uma perfeita interação entre as substâncias orgânicas, o oxigênio e as bactérias aeróbias do solo (DACACH, 1979).

Então, a DBO e a DQO mostraram-se alteradas para os pontos 01 e 03. Dessa forma, pode-se dizer que quanto maior a $\mathrm{DBO}$ e a DQO, mais elevado é o teor de matéria orgânica presente no material. Esses resultados podem ser atribuídos a seguintes situações. O Ponto 01 recebeu, além de resíduos da construção civil, outros tipos de resíduos sólidos, inclusive orgânicos, até o ano de 2000; por isso, a matéria orgânica ali presente encontra-se em franco processo de decomposição. Como existe dificuldade na depuração, por causa do volume e profundidade do aterro, ocasionando deficiência em luz e oxigênio, os efluentes gerados são carreados em concentrações elevadas para a água subterrânea. Assim, verificou-se na amostra coletada no período de chuvas valor ainda superior do que os do período de seca; já que, a parte percolada da água da chuva contribuiu para o carreamento do material em decomposição. No Ponto 03, apesar da ausência dos dados do período chuvoso, a presença da matéria orgânica é bem expressiva; pois, o local ainda vem sendo utilizado para o descarte e aterro do entulho e outros resíduos. Por fim, o Ponto 02, que teve a disposição encerrada em 1997, o que possivelmente contribuiu para a completa degradação da matéria orgânica, situação sugerida pelos valores destes parâmetros encontrados nas análises físico-químicas dentro dos limites da legislação ambiental brasileira (Resolução $\mathrm{n}^{\circ}$ 20/86, do CONAMA).

A dureza total e cálcica apresentaram valores elevados no período seco para o ponto 02 (115 mg. $\left.\mathrm{L}^{-1} \mathrm{e} 81,4 \mathrm{mg} . \mathrm{L}^{-1}\right)$. Já no período chuvoso os valores aumentaram tanto no ponto 01 (126 mg. $\left.\mathrm{L}^{-1} \mathrm{e} 93 \mathrm{mg} . \mathrm{L}^{-1}\right)$ quanto no ponto $02\left(208,5 \mathrm{mg} \cdot \mathrm{L}^{-1}\right.$ e 145 $\left.\mathrm{mg} . \mathrm{L}^{-1}\right)$. Pode-se atribuir esses resultados ao fato de que os íons cálcio e magnésio presente na água resultam da dissolução de carbonatos de cálcio $\left(\mathrm{CaCO}_{3}\right)$ ou de magnésio $\left(\mathrm{MgCO}_{3}\right)$, ou de qualquer outra substância que contenha cálcio (revestimento para cabos, adubo químico, gesso hospitalar, cimento e/ou concreto, material de carga para papel e tinta, por exemplo) ou magnésio (flash fotográfico, tijolo refratário, pigmentos, rodas de liga leve, por exemplo) (PERUZZO e CANTO, 1996). Dessa forma são liberados íons cálcio e magnésio, causadores da dureza (CETESB, 1974).

Quanto aos metais analisados, os resultados fornecidos pela DIAAQ, no período seco, todos os pontos apresentaram níveis inferiores a $0,1 \mathrm{mg} \cdot \mathrm{L}^{-1}$ para o alumínio, estando em plena concordância com a Resolução n ${ }^{\circ}$ 20/86 do CONAMA. No período chuvoso, apenas o ponto 02 apresentou valor superior ao limite $(0,5$ $\left.\mathrm{mg} . \mathrm{L}^{-1} \mathrm{Al}\right)$. O alumínio é um elemento encontrado em portas, janelas, iluminação e cimento (PERUZZO e CANTO, 1996). Sua presença vem alterar a turbidez da água, que é uma característica decorrente da presença de substâncias em suspensão, ou seja, 
sólidos suspensos finamente divididos em estado coloidal e organismos microscópicos (OLIVEIRA, 1978).

Para o cádmio, em todos os pontos e nas duas medições (seca e chuvosa) o resultado foi sempre inferior a $0,1 \mathrm{mg} \cdot \mathrm{L}^{-1}$. Entretanto, pelo CONAMA, o limite aceito para este metal é $0,01 \mathrm{mg} . \mathrm{L}^{-1}$. Nesse caso, não é possível afirmar se há traços de cádmio uma vez que, o limite de precisão do equipamento utilizado é $0,1 \mathrm{mg} . \mathrm{L}^{-1}$. $\mathrm{O}$ cádmio esta presente em baterias recarregáveis, filamentos de lâmpadas incandescentes, proteção anticorrosiva e pigmento vermelho-amarelo (PERUZZO e CANTO, 1996).

Segundo Pereira (1998), o cádmio existe também na fumaça resultante da queima do carvão de pedra e na fumaça do cigarro (um fumante de 20 cigarros por dia absorve $1 \mathrm{mg}$ de cádmio por ano). Ele é absorvido pelas vias digestivas (10\% do ingerido) e respiratória ( $40 \%$ do inalado). A intoxicação aguda se faz geralmente pela inalação de fumaças ou de pó contendo o metal. Seus principais efeitos são irritação das vias aéreas, podendo ocorrer edema pulmonar grave. Na exposição crônica, pode haver fibrose peribrônquica e enfisema pulmonar. Nos rins, as lesões aparecem quando as concentrações atingem $200 \mu \mathrm{g} / \mathrm{g}$; nessa situação, surgem lesões do epitélio tubular e proteinúria (DE PAOLA, 1977; PEREIRA, 1998).

Quanto ao chumbo, em todos os pontos e nas duas medições (seca e chuvosa) teve seu resultado inferior a $0,1 \mathrm{mg} \cdot \mathrm{L}^{-1}$. Segundo a Resolução n. ${ }^{\circ}$ 20/86 do CONAMA, o valor permitido é $0,05 \mathrm{mg} . \mathrm{L}^{-1}$. De forma análoga ao cádmio, o limite de precisão do equipamento utilizado é de $0,1 \mathrm{mg} . \mathrm{L}^{-1}$, torna difícil afirmar se esse resultado inferior a $0,1 \mathrm{mg} \cdot \mathrm{L}^{-1}$ indica concordância ou não com a legislação. $\mathrm{O}$ chumbo está presente em acumuladores de eletricidade, soldas, tubulações antigas, gasolina com alta octanagem e secante para tintas (PERUZZO e CANTO, 1996). Ele é absorvido pelas vias digestiva e respiratória, cai na circulação e se distribui nos tecidos moles, sendo posteriormente levado aos ossos (85\%), onde se deposita e de onde volta lentamente à circulação e aos tecidos moles. As principais lesões e manifestações de intoxicação pelo chumbo são denominadas de Plumbismo ou Saturnismo. Uma vez ingerido, o chumbo é fagocitado pelos macrófagos e transportado através dos vasos linfáticos aos linfonodos regionais e seu acúmulo progressivo produz uma coloração azulada das partes afetadas, como por exemplo, pulmões e rins, sob a forma de manchas irregulares no parênquima do órgão (DE PAOLA, 1977; PEREIRA, 1998).

\section{CONSIDERAÇÕES FINAIS}

Importantes questões foram diagnosticadas através da análise química da água, em três pontos da cidade de Uberlândia aterrados com entulho e outros resíduos sólidos associados. Vale ressaltar, que a escolha dos pontos de amostragem deveu-se 
especialmente pela facilidade de coleta e pela indicação precisa do aterro, por parte do poder público municipal; já que, a Secretaria Municipal de Serviços Urbanos da Prefeitura Municipal de Uberlândia, responsável por este serviço, não dispõe de um banco de dados com informações precisas sobre todas as áreas já aterradas.

Apesar das análises terem sido realizadas em número restrito, com prazo exíguo de realização e somado às dificuldades orçamentárias (que restringiram à amplitude das análises laboratoriais a serem realizadas, ou seja, além das análises físico-químicas, realizar-se-ia também as análises bacteriológicas), a ausência de informações por parte dos órgãos públicos responsáveis, e ao fato de alguns aterros ainda estarem em atividade (a exemplo do bairro Morumbi), os resultados constataram indícios de contaminação das águas subterrâneas. Por isso, o monitoramento precisa ser ampliado, tanto em relação aos parâmetros analisados quanto ao número de pontos de amostragem, para que o município passe a dispor de um banco de dados com informações mais definidas da qualidade das águas; bem como, possa traçar seu planejamento de saúde pública com vistas a minimizar as possíveis doenças a serem veiculadas através dos recursos hídricos.

Os resultados, também, demonstraram que é preciso repensar a questão da disposição do entulho no meio ambiente; pois, embora a legislação ambiental brasileira conceitue o entulho como material inerte, os sinais de contaminação apresentados neste estudo, confrontam às leis ambientais brasileira, alertam que o aterro não é o melhor destino para este tipo de resíduo.

Não obstante do ponto de vista ambiental, a cada dia mais, as cidades convivem com a dificuldade de disponibilizar áreas para aterros, devido ao crescimento urbano desordenado - áreas de aterro ficam impossibilitadas de se tornarem áreas de expansão imobiliária, por serem áreas que não apresentam condições estáveis para a ocupação humana uma vez que, o terreno, além da instabilidade natural caracterizada pela erosão, gera a acomodação (recalque) e facilita a percolação de efluentes. Outros inconvenientes podem ocorrer, tais como: excesso de umidade, falta de cobertura vegetal, exposição direta aos ventos e às chuvas e formação de gases por causa da decomposição anaeróbia da fração orgânica. Por todas essas razões, o aterramento com entulho não é uma boa estratégia dentro do planejamento urbano.

Assim, este estudo não é conclusivo, apenas contribui para propor solução deste problema e abre novas perspectivas para estudos futuros.

\section{REFERÊNCIAS}

BRANCO, S. M. Poluição - A morte de nossos rios. Rio de Janeiro: Ao Livro Técnico, 1972. p.18-48. 
CARACTERES químicos da água subterrânea. In: . Água subterrânea e poços tubulares. 2. ed. São Paulo, 1974. cap. 10.

CETESB-COMPANHIA TECNOLOGIA E SANEAMENTO AMBIENTAL-Água subterrânea e poços tubulares. 2.ed. São Paulo, 1974. cap. 10.

CREA-MG-CONSELHO REGIONAL DE ENGENHARIA, ARQUITETURA E AGRONOMIA DE MINAS GERAIS. Precariedade ressuscita doenças. Vértice, Belo Horizonte, n. 31, p. 4-5, maio 1998.

COSTA, N.R. A questão sanitária e a cidade. Espaço \& Debates, São Paulo, n.22, p. $5-25,1987$.

DACACH, N. G. Excretas, decomposição, destino. In:

Básico. Rio de Janeiro: Livros Técnicos e Científicos, 1979. cap. 7.

.Saneamento

DE PAOLA, D. Q; LOUREIRO, J. A. S; ÁVILA, C. M. Agentes químicos: drogas, tóxicos e poluentes. In: DE PAOLA, D. Q. Mecanismos básicos de doença. Rio de Janeiro, São Paulo: Atheneu, 1977. cap. 19.

FUNASA - FUNDAÇÃO NACIONAL DE SAÚDE - Curso Básico de Vigilância Ambiental em Saúde. Brasília, DF, 2001. 295 p.

MARTINS, N. F. O crescimento e a população humana: Uma ameaça? In: KUPSTAS, M. (Org.). Ecologia em Debate. São Paulo: Moderna, 1997. p. 61-78.

MÉTODO de perfuração de poços. In: Água Subterrânea e Poços Tubulares. 2.ed. São Paulo, 1974. cap. 10.

MINC, C. Ecologia e Cidadania. São Paulo: Moderna, 1997. 128 p.

OLIVEIRA, W. E. de. Qualidade, impurezas e características físicas, químicas e biológicas das águas. Padrões de potabilidade. Controle da qualidade da água. In: OLIVEIRA, W. E. de et al. Técnica de Abastecimento e Tratamento de Água. 2.ed. São Paulo, 1978. cap. 2.

PEREIRA, F. E. L. Patologia Ambiental. In: BRASILEIRO FILHO, G. Bogliolo Patologia. 6. ed. Rio de Janeiro: Guanabara Koogan, 1998. cap. 11.

PERUZZO, T. M.; CANTO, E. L. do. Classificação periódica dos elementos. In: . Química - na abordagem do cotidiano. São Paulo: Moderna, 1996. cap. 4. 
ROCHA, A. L. A situação do entulho no município de Uberlândia - MG, sob uma análise da legislação ambiental brasileira e do ponto de vista da população local. 2000. 40f. Trabalho de Conclusão de Curso (Graduação em Ciências Biológicas) - Instituto de Biologia, Universidade Federal de Uberlândia, Uberlândia, 2000.

SILVA, J. B.; COSTA, M.C.L.; DANTAS, E.W.C.(Orgs). A Cidade e o Urbano. Fortaleza: EUFC, 1997. p. 171-185.(Temas Para Debates). 